\title{
(Re)shaping educational research through 'programmification': Institutional expansion, change, and translation in Norway
}

\author{
Mike Zapp ${ }^{1}$ | Jo B. Helgetun ${ }^{2} \quad$ Justin J. W. Powell ${ }^{3}$
}

\author{
${ }^{1}$ Institute of Education \& Society, University \\ of Luxembourg, Luxembourg \& Stanford \\ Graduate School of Education, Stanford \\ University, Stanford, California \\ ${ }^{2}$ Institute for the Analysis of Change in \\ Contemporary and Historical Societies, \\ Université Catholique de Louvain, \\ Louvain-la-Neuve, Belgium \\ ${ }^{3}$ Institute of Education \& Society, University \\ of Luxembourg, Esch-sur-Alzette, \\ Luxembourg

\section{Correspondence} \\ Justin Powell, Institute of Education \& \\ Society, University of Luxembourg, 11 \\ Porte des Sciences, 4366 Esch-sur-Alzette, \\ Luxembourg. \\ Email: justin.powell@uni.lu
}

Funding information

University of Luxembourg

\begin{abstract}
Educational research in Norway has experienced unprecedented structural expansion and cognitive shifts over the last two decades because of greater state investments and the strategic use of extensive and multi-year thematic programmes to fund research projects. Using a neo-institutionalist framework, we examine institutionalisation dynamics in cultural-cognitive, normative and regulative dimensions by means of interviews, research programme calls, policy documents and funding data. In the cultural-cognitive dimension, we find references to the knowledge society, the perceived importance of evidence in policymaking and ideas of quality, excellence and relevance. In the normative dimension, we find the introduction of new professional and methodological standards, reflecting broader global patterns of academic and epistemic drift. In the regulative dimension, the strengthened role of both government and the Research Council of Norway is manifest in substantial growth in both funding and large-scale, long-term planning, including thematic choices-evidence of 'programmification'. The importance of external models has grown in an era of internationalisation, yet translation occurs at every level of the governance of educational research. This results in a specific Norwegian research model, guided by a mode of governance of programmes that maintains social values that are traditionally strong in Nordic societies.
\end{abstract}

\section{NORWEGIAN EDUCATIONAL RESEARCH IN THE CONTEXT OF INTERNATIONALISATION}

Norwegian educational research is analysed here in the context of the global institutionalisation of the university (Schofer \& Meyer, 2005) and scientisation in which the dissemination and translation of certain models of research that inspire change in national contexts are crucial (Drori, Meyer, Ramirez, \& Schofer, 2003). Neo-institutionalist research has shown worldwide isomorphism in terms of expansion, structure and contents for a variety of policy fields; 
particularly education (Meyer, Boli, Thomas, \& Ramirez, 1997). Our focus is on the growing isomorphism among research systems and their governance, with the university most often the key organisational form leading to innovation (Meyer \& Frank, 2007) and producing most scientific publications (Powell, Baker, \& Fernandez, 2017). We ask whether educational research has undergone processes that resemble the legitimacy-seeking and institutionalisation found in (higher) education systems. We argue that educational research that often has a national orientation has become increasingly prone to exogenous influences in recent decades. Notably, international organisations have exerted considerable cognitive and normative influence on diverse arenas of educational research, particularly with the proliferation of international large-scale assessments (ILSAs) (Gläser et al., 2014; Sellar \& Lingard, 2014; Zapp \& Powell, 2016). States, in their quest for evidence upon which to base policymaking decisions, channel funds into large-scale programmes, establish new and rebrand old research organisations and, increasingly, launch comprehensive and controversial research evaluation systems that reshape scientific activities, from preferred publication formats to choice of topic (Marques, Powell, Zapp, \& Biesta, 2017). Importantly, policymakers strategically (re)shape research by sponsoring thematically-specific programmes.

If many countries have expanded their higher education systems and educational research through increased funding, Norway presents a case of considerable government influence on educational research through specificallydefined thematic programmes or 'programmification' (Maylor, Brady, Cooke-Davies, \& Hodgson, 2006). Lacking in many broader analyses, however, are more detailed accounts of a lower-level adoption of global and regional ideas and norms which we address here. We apply familiar concepts of isomorphic change from the neo-institutionalist sociology of organisations that stresses regulative, normative and mimetic processes (Scott, 2013). However, we neither expect an unfiltered adoption of external models tout court nor assume that all elements of global models will be implemented, even if some resemble national models and systems. Instead, we focus on concrete processes of institutionalisation in a specific national context. To explore the conditions of lower-level diffusion and adaptation, we draw on concepts of translation and editing that constitute the core of Scandinavian institutionalism (Czarniawska \& Joerges, 1996; SahlinAndersson, 1996; Suárez \& Bromley, 2016). They facilitate a deeper understanding of how various forms of knowledge are blended, adapted or reinvented in specific settings and how they ultimately (re)shape institutions, organisations and entire research fields.

Norway, which is underrepresented in the research literature, is a valuable case to examine the influence of global and European models. Often viewed as a late reformer in higher education, the Norwegian infrastructure for conducting educational research has experienced remarkable expansion and substantial structural and paradigmatic change since the 1990s (Bleiklie, 2009; Larsen, 2000). We find academic and epistemic drift, that is, shifting orientations, standards and criteria with regard to scientific priorities and principles and their relevance (Elzinga, 1997; Kaiserfeld, 2013). This formative phase, we argue, is very fruitful for revealing the processes that are currently reshaping educational research in Norway, across Europe and internationally.

First, we introduce our theoretical foundations and scope to frame the analysis. Second, we depict key features of Norwegian higher education and research governance and briefly chart the history of the institutionalisation of Norwegian educational research. Third, we discuss the data sources and methods applied. To capture recent changes, we examine institutionalisation dynamics via interviews, policy documents, research programme calls, educational research projects and funding data. Fourth, we present our findings, structured by the cultural-cognitive, normative and regulative processes involved. In the cultural-cognitive dimension, we find references to the knowledge society, the importance of evidence in policymaking and notions of quality, excellence and relevance. In the normative dimension, we find the introduction of new professional and methodological standards, reflecting broader global patterns of academic and epistemic drift. In the regulative dimension, the strengthened roles of the government and the Research Council of Norway (RCN) are manifest in substantial growth in both funding and large-scale, long-term planning, including thematic choices-evidence of programmification (see e.g., RCN, 2006). Norway's government and RCN have adapted diverse mechanisms of governance to support the widespread development of educational research. Programmification emphasises certain themes in education, as well as quality and excellence generally, the importance of methodological standards and evidence and societal relevance. These new funding priorities have an impact on researchers' 
rationales and priorities, entailing lasting epistemic drift (Elzinga, 1997; Kaiserfeld, 2013). Finally, we discuss the specific translation work leading to the distinctive shape of Norwegian educational research and re-contextualise the case of Norway within wider international trends.

\section{2 | DIMENSIONS AND PROCESSES OF INSTITUTIONALISATION: IDEAS, STANDARDS AND POLICIES}

Defining institutions, Jepperson (1991, p. 145) writes of 'stable designs for chronically repeated activity sequences'. These designs come in various forms and their embedding in social life follows various logics. Following DiMaggio and Powell (1983) and Scott (2013), we analyse institutionalisation processes that reflect ideas (cultural-cognitive), standards (normative) and policy (regulative) mechanisms that drive reproduction and change. Each of these dimensions suggests a different rationale for legitimacy, either by virtue of being legally-sanctioned (regulative), morally-governed (normative), or culturally-supported (cognitive). As (organisational) actors seek to survive and flourish, they invest in conformity to the rules and belief systems that prevail, often beyond evidence of technical value or efficiency. Institutional isomorphism, both structural and procedural, is expected to earn actors the key good of legitimacy (Suchman, 1995). The main task of much institutional analysis has been to identify the most important forces in a given context and the extent to which these mechanisms reproduce or change the institutional order-or replace it altogether.

Institutional analyses have explored the construction and evolution of various organisational fields, including international human development and education (Chabbott, 2003) or academic research (Cruz-Castro \& Sanz-Menéndez, 2007). In education, recent applications of this type of institutional analysis chart the emergence of a European model of skill formation (Powell, Bernhard, \& Graf, 2012), whilst others trace the creation of an organisational field in German educational research that is strongly quantitative, applied and internationally-oriented (Zapp \& Powell, 2016). For Norway, Larsen (2000) analysed government authorities' attempts to establish standards via research policy at the university level in the mid- to late-1990s. She found that universities and individual actors reacted very differently to these normative pressures, suggesting a potential decoupling between external demands and internal compliance. Similarly, Karseth and Sivesind (2010) saw global cognitive blueprints at work in the redesign of the Norwegian curriculum, whilst Elstad and Sivesind (2010) confirmed that the OECD-PISA assessments of student performance were a source of legitimacy in contemporary Norwegian education policymaking in general.

These European and Norwegian studies show institutionalisation as reflecting a considerable interplay of factors, originating from different levels and dimensions at various stages of change processes. As exogenous institutional pressures in the guise of powerful ideas encounter extant structures and cultures, there results much 'bricolage' (Campbell, 2004; Powell, Bernhard et al., 2012; Weick, 1993). Hence, we elaborate on classical models of institutional change in two ways. First, we grant theoretical and analytical primacy to the cultural-cognitive dimension because we assume that ideas are powerful factors, especially at the incipient stages of institutional change (Campbell, 2004). More precisely, (inter)national discourses around educational and social development have long been dominated by a highlyinstrumental ideology of science. In this 'science for development' policy model, science is understood as a national, systemically-planned, realist, economically-viable and utilitarian tool to foster progress (Drori et al., 2003). National policymakers, often supported by international organisations, continue to regard scientific activity as a key to guarantee attainment of national development goals (Finnemore, 1993; Hwang, 2006).

Second, we discuss such ideologies or meta-scripts of national progress through education and science as aggregated in models that contain 'traveling ideas' that 'built a bridge between the passing fashion and a lasting institution' (Czarniawska \& Joerges, 1996, p. 36). Thus, assuming that ideas and policies 'morph as they move' (Cowen, 2009, p. 315), we must pay attention to the specific translation processes at subsequent levels (Czarniawska \& Joerges, 1996; Karlsson, 2017; Sahlin-Andersson, 1996). Neo-institutionalists often stress that an idea moves in time and space, but also through different ontological states: a moment and place witness an idea that is translated into an object and then into action. In repeating and formalising such action, it may gradually stabilise into an institution that is legitimate and taken-for-granted. Applying this to the case of Norway, we expect that national efforts to reform educational 
research will reflect supranational models whilst continuously mediating and negotiating their impact based on extant regional and national models. We also expect that education researchers will translate such models, as they propose legitimate research that also serves Norway.

Such insights have been applied to education generally. Maroy (2009, p. 75), for instance, identified 'hybridisation of [supranational] models with local elements' when analysing Member States' reaction to EU initiatives to enforce evaluation practices and quasi-market principles in education systems. Speaking of bricolage, similarities between supranational European and traditionally-influential national models in education and skill formation facilitate the translation process yet do not ensure corresponding implementation at lower levels to reflect the explicitly agreed-upon model (Powell, Bernhard et al., 2012). In fact, divergence may result as much as convergence (Powell, Graf, Bernhard, Coutrot \& Kieffer, 2012). And, although Karseth and Sivesind (2010) find an increasingly globalised and individualised curriculum taking shape in Norway, they cannot confirm the disappearance of the nation-state as the crucial frame of reference. Thus, institutional change is rarely radical, as exogenous pressures meet forces of inertia, often leading to path-dependent, incremental change (Mahoney \& Thelen, 2010). How translation and editing are carried out may help to explain why even countries that implement similar reform projects do so along such different pathways and with such diverse consequences. Hence, particular attention will be given to the translation of exogenous scripts that are interpreted and then integrated into a distinctly Norwegian model.

In the cultural-cognitive dimension, we expect strong references to general themes such as evidence for policy, quality, relevance and internationalisation, all currently high on global agendas (Chou \& Gornitzka, 2014; Nutley, Morton, Jung, \& Boaz, 2010; Whitley \& Gläser, 2007). Yet we also expect Nordic and Norwegian translations because of the strong social-democratic welfare state that combines the concerns of economic competitiveness and social cohesion in general with inclusion and equality in education in particular (Green, 2006).

In the normative dimension, we expect systematic efforts to professionalise and standardise educational research, as reported for a wide array of other organisational fields (Chabbott, 2003; Larsen, 2000). Issues of certification, accreditation and evaluation are classical avenues for such investigation, stressing the interplay between various interest groups such as professional associations and regulatory agencies (Greenwood, Suddaby, \& Hinings, 2002). Yet we apply a dynamic view of boundaries, identities and agency in the Norwegian context that is traditionally marked by consensualism in decision-making, a high degree of social security and career stability and the spanning of boundaries between policymaking and research activities (Bleiklie, 1998; Bleiklie \& Michelsen, 2013; Strand \& Kvernbekk, 2009; Telhaug, 1978). Thus, we expect strong Nordic norms to block a verbatim translation of global scripts and the resulting interpretations to be congruent with regional, national and local legitimated priorities.

Finally, in the regulative dimension, we examine politics and governance, such as the actors involved in decisionmaking and educational research funding. We investigate the role of the government and its subordinate units, particularly the Research Council of Norway (RCN) as the symbolically crucial, leading research policy organisation. Here, we expect translation efforts in the guise of incentives for research that reflect Nordic welfare principles revolving around notions of inclusion, cohesion, solidarity and justice.

These three dimensions help to analyse the complex processes in Norwegian educational research governance and their reshaping since the late 1990s. We next ground our analysis with a brief historical overview of Norwegian educational research.

\section{3 | THE ORIGINS OF NORWEGIAN EDUCATIONAL RESEARCH AND THE RISE OF THEMATIC PROGRAMMES}

The early phase of Norwegian educational research was strongly influenced by Reform Pedagogy, as reflected in the first national curriculum (1939) that stressed child-centredness and cooperative learning, the interplay of three founding disciplines-psychology, didactics, and history-and, on the policy side, a unanimous normative agreement on the 'unified school' that is emblematic of the traditionally-strong social consensualism in Norway (Dale, 1999; Helsvig, 2002). The research field grew in the following decades, absorbing philosophical, sociological and cultural approaches. 
Later, new topics such as curriculum studies, special (educational) needs, policy studies and ICT were added. Nevertheless, Norwegian educational research was long relegated to a niche existence (Lauglo, 1994). Tellingly, until the late 1980s, it was funded as part of general institutional funding (Gudmundsdottir, 1994), which remains the bulk of funding for research capacity today.

This situation was officially addressed with the first thematic educational research programme. As from 1989, the programme for utdanningsforskning (educational research abbreviated as PUF) funded more than 70 research projects (Lauglo, 1994). Whilst educational research before the 1990s had been largely synonymous with humanities-based pedagogikk, this programme formally established an emphasis on practice-based research in which user-oriented research and proximity to the field of practice were considered vital. Gradually, empirical studies rose in importance, reducing the dominance of educational theory and philosophy (Gudmundsdottir, 1994). PUF was followed by other smaller thematic programmes in the 1990s. They constructed an infrastructure for educational research that gradually became more multidisciplinary, inter-sectoral and topic-focused. Most current educational research is conducted in eight public research universities where research and teaching mandates are balanced, unlike in the høgskoler with their strong teaching focus (Gunnes \& Rørstad, 2015). But mergers in higher education and the redefinition of university colleges, exemplifying the global phenomenon of academic drift following higher education expansion, have extended research capacity beyond the key research universities. The first evaluations of this nascent Norwegian research infrastructure, carried out in 2002 by the RCN, concluded that strong disparities in quality remained. This diagnosis laid the groundwork for intensified subsequent government efforts to provide educational research with more resources, more organisational diversity, an international outlook and clear thematic priorities-the focus of our analysis.

\section{4 | METHODS AND DATA}

To analyse institutional change in Norwegian educational research, we gathered data at three levels: policy, programmification and science. At the policy level, we analysed all major white papers dealing with R\&D during the period 2000-2015 and gathered the available quantitative data on funding, its distribution and its evolution. At the programmification level, we studied the five major RCN research programmes in education launched between 2003 and 2014. For the science level, we drew on selected findings from the 'The New Governance of Educational Research' (EDRESGOV) project that charts the evolving governance, evaluation and contents of educational research across Europe. This study's Norwegian component comprises a qualitative content analysis of 141 projects conducted from 2006 to 2015. It was based on overarching categories along the three dimensions of institutionalisation explained above, whilst further categories were inductively gathered, refined and abstracted. To ensure reliability, documents were coded independently by at least two members of the research team, with intercoder agreement at almost $95 \%$ (measured using MAXQDA). Furthermore, we conducted seven semi-structured expert interviews with actors from policy, research planning and science (Bogner, Littig, \& Menz, 2009). ${ }^{1}$ We chose to interview those who were active in educational research throughout the observation period and those whose roles were multiple and boundary-spanning, such as researchers, advisory board members and project leaders. Interviews presented here are coded by A for actor and a consecutive Roman numeral in order to ensure anonymity.

\section{5 | (RE)SHAPING NORWEGIAN EDUCATIONAL RESEARCH}

\section{$5.1 \mid$ The cultural-cognitive dimension}

We find many explicit references to familiar key themes from the global educational research agenda revolving around educational metrics, evidence, performance and excellence (Besley, 2009; Biesta, 2007; Meyer \& Benavot, 2013). They are confirmed for various actors at multiple levels of the policymaking process. First, we find the recurrent stress on utilitarian rationales for supporting educational research, indicated by frequent references to the 'knowledge economy'. The Nordic Council (NC), for instance, initiated the long-term research programme, Education for Tomorrow, that shed light on 'research questions of social relevance' to better 'equip Nordic education systems to meet the needs of 
society' (NC, 2016). Similarly, the national government emphasised that 'education should be focused on how education can help the nation's industry, and provide economic gains to Norway' (Meld St. 7 2014-2015). Other statements on the promised utility of educational research can be found in almost all state-initiated programmes. UTDANNING2020, for example, which ran from 2009 to 2014, was funded to face the 'challenges for the [education] sector [...] in light of the globalisation processes of which Norway is a part and the demands being placed on education in today's knowledge society' (UTDANNING2020, 2010, p. 11).

Another theme emphasises that, in order to harness the benefits of education, educational research must move closer to the policymaking arena. The government has stressed evidence-based approaches to social problems in its white papers since 2008 (Meld St. 30 2008-09; Meld St. 7 and 18 2014-2015). The Ministry of Education and Research (MER) takes pride in working with the policy-consulting agency Campbell Collaboration (Regjeringen.no 2013; Campbell Collaboration, 2016). Indeed, many research programmes initiated since the late 1990s take evidence for policymaking as the overriding rationale. For instance, the primary goal of the Programme for Research and Innovation in the Educational Sector (FINNUT 2014-2023) is to 'develop knowledge of high quality and relevance for policy development, the public administration, the field of practice, and the individual' (FINNUT, 2014, p. 6). In 2013, the Knowledge Center for Education was launched as a department of the RCN to 'contribute to knowledge-based policy work, management and practice' (KCE, 2016).

Researchers also report a strong interest at the policy level, as '... the Ministry wants to increase the competencies in Norway in order to develop research and to use research for policy and decision making' (A IV). Furthermore, they voice their opinions on where this emphasis comes from: 'I think the evidence movement [...] parallel[s] in a sense educational research within the OECD' (A IV; A III). Strongly related to emphasis on evidence, greater attention has been given to international large-scale assessments (ILSAs). The Nordic Council (2016) frames the results from such tests in Scandinavian terms, increasing regional comparisons. However, some researchers consider the OECD-PISA study as the root of current developments in educational research generally:

I first heard about the term PISA shock in Germany, but I think the shock was just as big in Norway as it was in Germany. [... I I could say that PISA has been very good for Norwegian educational research because it was realized that we are not so good and we do not know why (A IV).

The 'quality' problem diagnosed in the educational system quickly became transposed to educational research. Research programmes such as UTDANNING2020 (2010, p. 5) have been introduced with sober judgements about an educational research field that 'is fragmented and characterised by varying quality, weak internationalisation, and a lack of recruitment at all levels within academia' (FINNUT, 2014, p. 12; Meld st. 7 2014-2015). Researchers partly confirm the justified interest in increasing research capacity and quality for educational research in general and for teacher training in particular (A III; A IV). We find calls for more 'excellence', 'professionalization' and 'internationalization', which are often viewed as highly interdependent. This constellation is heavily emphasised in key R\&D policy papers (Meld st. 7 2014-2015; Meld st. 30 2008-2009; Meld st. 18 2012-2013). For example, the first paper states that:

Norway is trailing behind countries we compare ourselves to in terms of quality in research. In addition to a thorough focus on quality in research and higher education, the government prioritises a distinct focus on world-leading academic communities. This is necessary in order to stimulate an increased acceptance and international visibility for Norwegian research (Meld st. 7 2014-2015: 5f.).

\section{2 | The normative dimension}

In the normative dimension, we find similar actors. They reshape the global scripts and cognitive blueprints identified above into novel expectations, standards and practices in educational research. This is most visible regarding the putative 'quality problem' in Norwegian educational research. Aiming to take stock of the early reforms in governance initiated during the 1990s, the RCN carried out the first educational research quality evaluation in 2002, finding a growing discipline that currently accounts for the largest disciplinary share in Norway's higher education system. Of a 
total of 3,595 researchers, 972 were in education, $30 \%$ of whom were employed at universities and $70 \%$ at university colleges (høgskoler), emphasising the importance of academic drift, as teaching-oriented university colleges employ the majority of education researchers. Yet, as in other countries and fields, this evaluation diagnosed large quality disparities, both between and within organisations (Zapp \& Powell, 2017).

As a step towards greater output and quality in research, the government initiated the Current Research Information System in Norway (CRIStin), which was first implemented in 2005, used to distribute funds in 2006 and evaluated in 2013-14 (Aagaard, Bloch, \& Schneider, 2015). As a unique model in performance-based research funding, the Norwegian system includes a meta database containing all publications by research staff employed by Norwegian scientific organisations across the disciplines, awarding points to authors according to the type of publication (e.g., books, articles) and publication outlet, with the latter measured according to selectivity and perceived reputation (Sivertsen, 2016). Unlike other funding models, the Norwegian model transforms publication counts into points according to quality criteria about the outlets. However, only $2 \%$ of the funds for the higher education sector are distributed according to these indicators. It was found that publication activity increased, impact remained stable and that there was no indication of shifts to lower-impact journal publication to increase output (see Schneider, Aagaard, \& Bloch, 2015 for a comparison of research evaluation in Norway and Australia).

A further theme is the strong encouragement for researchers to internationalise their scholarship. This takes centre stage in the white paper Commitment to Research (Report no. 20 to the Storting, 2004/05, p. 3):

The Government's goal is to ensure that Norway occupies a leading position internationally in terms of new technology, skills and knowledge [...] with regard to measurable research results, i.e. the number of scientific publications, citations and patents, success in the EU's framework programmes [...].

Internationalisation is also a key theme in the RCN's International Strategy (2010-2020), as it was in Research Expands Frontiers (up to 2010). All major programmes encourage English-language publications, international collaborations, cross-national research topics and participation in international conferences (FINNUT, 2014, p. 26; PRAKSISFOU, 2006, p. 13; PRAKUT, 2011, p. 18; UTDANNING2020, 2010, p. 7). Sometimes specific references to the 'European Research Area' (the EU Framework Programmes and particularly Horizon 2020) and the need to 'strengthen bilateral research cooperation, particularly with countries in North America and Asia' (UTDANNING2020, 2010, p. 21) provide clear incentives, norms and conditions concerning the design of research proposals and desirable collaborations.

A topic of concern is that publication behaviour marks a generational divide between younger and more established researchers. One junior researcher believes that ' [ . . ] there is some kind of focus on getting more international projects' and that 'the academic publication is very English oriented' (A II). In contrast, a distinguished senior academic looks back on her career, confirming that 'despite being international in some sense, back then no one expected researchers to write in English' (A IV).

Another normative theme is the debate on the professionalisation of educational research and teacher education. Interviewees explicitly mentioned 'academic drift' (A II; A IV) as affecting both areas. Here, the establishment of training programmes, graduate programmes and excellence centres, together with a general trend towards producing more $\mathrm{PhDs}$ in educational research, are prophetic examples. This new infrastructure is sometimes built upon, yet often replaces older practices in teacher education and research. Traditional practice-based teacher education is now challenged by a novel premium on research-based education 'because first of all there's a lack of good research in the field of teacher education, it's been much more practice-oriented' (A III). This perception of the quality of qualitative research is also reflected in the encouragement to conduct quantitative research that is found in the more recent research programmes. PRAKUT (2011, pp. 8-9) states that:

Up until now, qualitative research has been the main methodological focus [...]. In the future, it will be necessary to conduct a critical review of how a qualitative approach can ensure research quality and at the same time maintain a practice-oriented development perspective. Also, there is the need to strengthen the quantitative dimension [...]. 
TABLE 1 R\&D expenditures (total; education), Norway, 1994-2013 (in NOK, millions)

\begin{tabular}{|llllll|} 
& 1994 & 2007 & 2009 & 2011 & 2013 \\
\hline Total R\&D expenditures & $/$ & 36,788 & 41,884 & 45,440 & 50,748 \\
\hline Total R\&D expenditures on ER & 12 & 548 & 820 & 1,096 & 1,138 \\
\hline Expenditures on ER \% of total R\&D & $/$ & 3 & 3.5 & 4.6 & 4 \\
\hline $\begin{array}{l}\text { RCN expenditure on ER } \\
\text { (\% of total RCN expenditures) }\end{array}$ & $/$ & $69(12 \%)$ & $94(11 \%)$ & $/$ & $125(11 \%)$ \\
\hline
\end{tabular}

Source, NIFU; Halvorsen (1994).

Notes. Unfortunately, data on research funding in general and on educational research funding are difficult to obtain (see Lepori et al., 2007 for a description of the formidable challenges in gathering reliable and comparable longitudinal research funding data for various countries, including Norway).

Hence, research programmes call for more 'social science research on the outcomes of education, including the effects of educational interventions, as well as research based on longitudinal studies and empirical research and research based on quantitative data' (UTDANNING2020, 2010, p. 9). Encouraging 'diversity of methodologies' in this context means 'increasing the volume of quantitative research' (FINNUT, 2014, p. 17; UTDANNING2020, 2010, p. 14). Such a 'swing from qualitative to quantitative approaches' (A I) is also mirrored in the founding of the University of Oslo's Centre for Educational Measurement (CEMO). Here, the link between methodology and evidence claims becomes clear, as CEMO plays an explicit advisory role for the MER, the Norwegian Agency for Quality Assurance in Education (NOKUT) and the Norwegian Directorate for Education and Training (CEMO, 2016). The RCN seeks to strengthen this trend, calling on education researchers to 'produce research that is useful in public debates and within the schools [.. .] and to employ relevance criteria rather than scientific quality criteria' (RCN, 2004, p. 9). Furthermore, since 2004, yearly mandatory assessments (national tests or nasjonale prøver) have been conducted in Mathematics, Norwegian and English for students in grades 5, 8 and 9. These tests, administered by the Directorate of Education (Utdanningsdirektoratet), which also sets the curriculum, provide results that are available to researchers and the public on a school-by-school basis. Thus, not only are new ideas shaping educational research, but particular norms are also being strengthened, from relevance and quality to professionalisation and evaluation to internationalisation, publication behaviour and academic and epistemic drift. Turning now to the regulative dimension, we show how policymaking and governance affect educational research and researchers across the country.

\subsection{The regulative dimension}

The regulative dimension assesses the credibility of actors' calls for reforms of educational research and the extent to which rhetoric has been implemented. One key aspect which has received little attention so far is the general expansion of educational research and its related funding. The Norwegian government is the key actor in research governance via its direct funding through block grants to higher education organisations, resources for the RCN and defined programmes within a specified research agenda. Indeed, most educational research (84\%) in Norway is publicly-funded (Gunnes \& Rørstad, 2015).

The MER has been responsible for coordinating all educational levels since 1991 (also Kindergartens since 2006). As the main coordinator of research through the twin mechanisms of block funding of the education system and R\&D and writing white papers and initiating research programmes to fund particular projects, it administers and contributes more than a third of the funding distributed by the RCN. Based on available data, resources for R\&D in general and educational research in particular have risen considerably in the last 15 years (see Table 1). Since the 1990s, the funding of educational research has increased by a factor of nearly ten, yet as a percentage of total R\&D it received just around 4\% in 2013. RCN remains an important funder throughout the period, with about $11 \%$ of its total annual resources devoted to educational research. 
TABLE 2 Thematic research programmes in education, Norway, 1997-2015

\begin{tabular}{|c|c|c|c|c|}
\hline & Focus & Period & $\begin{array}{l}\text { Budget } \\
\text { (NOK mill.) }\end{array}$ & $\mathrm{N}$ of projects \\
\hline KUV & Relationship between education and society & $97-02$ & / & / \\
\hline KUPP & Teacher professionalisation & $99-04$ & 50 & 32 \\
\hline KUL & $\begin{array}{l}\text { Research competencies; knowledge } \\
\text { development; public awareness }\end{array}$ & 03-07 & 85.5 & 14 \\
\hline PRAKSISFOU & $\begin{array}{l}\text { Teacher professionalisation; research } \\
\text { and practice; learning processes }\end{array}$ & $05-10$ & 152 & 31 \\
\hline UTDANNING2020 & Learning outcomes; governance & $09-14$ & $108.8^{\mathrm{a}}$ & 43 \\
\hline PRAKUT & $\begin{array}{l}\text { PRAKSISFOU plus early childhood; } \\
\text { knowledge transfer }\end{array}$ & $10-14$ & 115 & 38 \\
\hline FINNUT & Learning outcomes; governance & $15-23$ & 196 (ongoing) & 102 (ongoing) \\
\hline
\end{tabular}

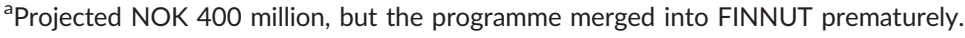

Source. Authors' compilation based on programme data sources.

Some research organisations and university departments have benefitted hugely from such investments. One interviewee saw the institute rapidly grow from 20 to 130 people (A III), whilst another noted that a department in teacher education had offered around 20 new associate professor positions within a very short period (A IV). The government, through the RCN, has established a series of thematic research programmes in education. Seven have been launched since 1997, each with a different thematic focus and comprising a considerable number of research projects (Table 2). They represent investments of around NOK 556.3 million (roughly $12 \%$ of annual educational research funding). Thematic educational research programmes represented a relatively modest share, around a tenth of all funding on average over the last decade (Gunnes, 2009; Gunnes \& Rørstad, 2015), given the high costs of infrastructure and the building of organisational capacity throughout the country. Yet the researchers we interviewed confirmed the high symbolic importance of large-scale programmed research. The government plays a strong direct role, as does the RCN, in shaping the educational research agenda:

[...] the Ministry will put into their yearly budget that they will support a ten-year or twenty-year program on educational research [...]. And then there would be an appointment of a commission or a board to start to develop an agenda for the research program. And then [. . . ] its finalized and you have a program [...] this is really where you try to govern research... in a very administrative way (A IV).

As mentioned above, the government also funded the establishment of organisations such as the Norwegian Agency for Quality Assurance in Education (NOKUT, ${ }^{*} 2003$ ), the National Graduate School in Educational Research (NATED, *2009), the National Research School in Teacher Education (NAFOL, ${ }^{*} 2010$ ), the Knowledge Centre on Education (*2013) and the Centre for Educational Measurement (CEMO, $\left.{ }^{*} 2013\right)$. Together, they add up to a considerably expanded educational research landscape that supports and evaluates novel methodological profiles and international orientation and outreach. Their work has been facilitated by legislative reforms such as national testing.

Funding as a regulative mechanism also facilitates internationalisation-and specifically Europeanisation-in that each Euro received from a European funding agency, whether through the Framework Programmes or the European Research Council (ERC), receives additional matching amounts of Norwegian Kroner from the RCN, thus providing huge incentives for high-level international collaboration (A III). Often, internationalisation and quality are seen as intertwined and are supported accordingly. The Nordic Centre of Excellence: Justice through Education in the Nordic Countries (JustEd), for example, was established in 2013 as a multi-country consortium. Norway also launched an excellence strategy for education in 2010 , including teacher education-with more to follow. All display their internationality, which is even required as a key funding criterion in the NOKUT calls (NOKUT, 2016). 
Thus, the cultural-cognitive, normative and regulative dimensions interlock and the corresponding change processes have reshaped educational research by expanding the higher education and science systems, especially with regard to research capacity and its overall quality and relevance. Yet the global trends and international elements are filtered through a particular context with translation that is sensitive to Nordic and Norwegian perspectives, to which we now turn.

\section{IRANSLATING GLOBAL TRENDS INTO NORWEGIAN EDUCATIONAL RESEARCH AND GOVERNANCE}

This case study suggests the overlapping of cultural-cognitive, normative and regulative processes that have reshaped Norwegian educational research. We found an expanding organisational scientific infrastructure for (higher) education with close ties to national policymaking, international research, standards and evaluation procedures, as well as the ongoing demand for more professionalisation and the ever-elusive 'quality'. What remains to be discussed in gauging the impact of (inter)national influences and trends is specific translation processes across the dimensions, from culturalcognitive to normative to regulative and the mechanisms and actors involved (Table 3 ).

Translating the cognitive impact. Meta-ideas of the knowledge economy and global and regional competitiveness spread and raise awareness worldwide. However, they are not received without interpretation and translation. Hence, the knowledge economy is carefully but consistently edited as the knowledge society in documents issued by the Nordic Council (2016) and the MER (Meld st. 30 2008- 2009; Meld St. 7 and 18 2014-2015). Tellingly, the only Nordic Excellence Center in Education deals with the issue of justice in times of globalisation against the backdrop of 'values and political ideals underlying the Nordic democratic educational project' (NC, 2016).

In our analysis of 141 projects, the second most frequent theme on the research agenda was social justice and cohesion. Taken together, projects focusing on equality, inclusion and welfare account for a fifth (19.6\%) of all projects analysed, slightly below teaching and learning improvement (21.3\%). This not only reflects strong and lasting values enshrined in Nordic policymaking, including education policy (Gundem, 1993; Lauglo, 1994; Karseth \& Sivesind, 2010), but also contrasts strongly with other countries in which ideas of teaching and learning and societal impact (UK) and teaching and learning and professionalisation (Germany) were prioritised during the same period (Zapp, Marques, \& Powell, 2017).

Further translation can be observed regarding international assessments and their impact in policy debates. Whilst some researchers turned the PISA results into a catapult for their own careers and organisational consolidation, this view is not universal, particularly at the policy level. The only time a Norwegian white paper directly mentions ILSAs is as a passing remark in Meld st. 16 2001-2002 which states that Norwegian 15-year-olds achieve the OECD-PISA average, yet do less well than 'our neighbour Finland'. An interviewed RCN official stated flatly that 'PISA is not a thing we are interested in' (A X). This resembles the trajectory of The Netherlands where PISA was largely ignored by the research community and contrasts with Sweden and Switzerland where international assessments had a major impact by strengthening their limited quantitative research traditions before participation (Gläser et al., 2014). Such a mediated impact of PISA contrasts starkly with Germany where the first PISA round in 2000 sparked widespread public outcry and political action, opening a window of opportunity for a new (empirical, quantitative and applied) methodological paradigm to emerge, also supported by public investments in capacity-building and thematic funding programmes in educational research (Zapp \& Powell, 2016, 2017).

Translating the normative impact. Although scientific output measurement was introduced through CRIStin, it serves as a soft governance instrument that indicates the pace of 'progress' rather than strongly regulating performance. Supporting this argument, neither CRIStin nor the annual ministerial reports rank scientific organisations, but rather sort them alphabetically. Moreover, premium points awarded to authors through the system are attributed on an equal basis (whole counting method), not as a function of their author sequence or contribution (fractional counting method). Internal reviews and audits are preferred. NOKUT encourages organisations to self-audit but does not directly evaluate the quality of organisations. Such soft steering through evaluation contrasts with stronger versions 

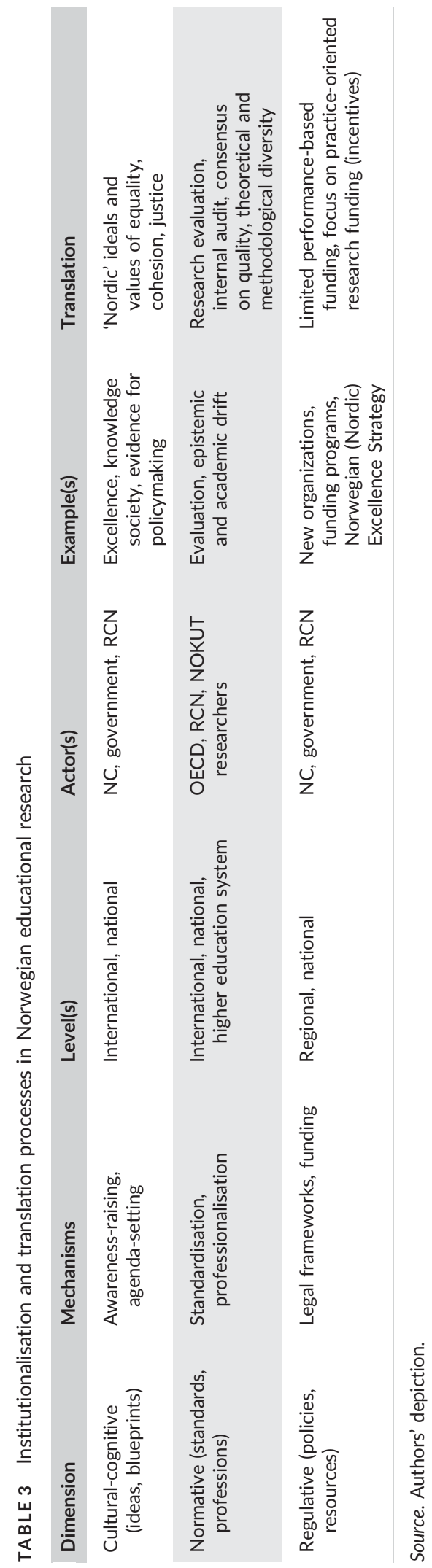
found, for example, in the UK's Research Excellence Framework (Marques et al., 2017) and in Sweden (Besley, 2009; Foss Lindblad, Lindblad, \& Popkewitz, 2009). This confirms continuity with regard to research governance observed in particular for Norway in the 1990s (Larsen, 2000).

Another example of how national norms mediate exogenous pressures can be found with regard to the methodological paradigms that are recommended in thematic research programmes. Although recent programmes (KUL, PRAKSISFOU) encourage quantitative research designs, marking a clear shift compared to earlier programmes, they do not overwrite the traditionally strong focus on practice-based research in Norway. PRAKUT (PRAKsisrettet UTdaningsforskning or practice-based educational research) argues just as strongly as PRAKSISFOU for practice-based research approaches that are still present in FINNUT and PRAKUT. Our analysis of educational research projects shows that $37 \%$ primarily adopt this approach. Thus, the visible trend towards quantitative research does not translate into a fundamental critique or abandonment of others. This contrasts with the state-induced, methodological clash that divides the scientific community producing educational research scholarship, for example, in Germany since 2000 (Zapp \& Powell, 2016, 2017).

Translating the regulative impact. Our analysis has shown a remarkably strong involvement of public actors in governing both the structure and content of educational research and education more generally. Concerning the legal autonomy of the RCN, its official status is that of a 'subordinate agency' of the MER and a 'national strategic body for research' (MER, 2016). Although this may be unthinkable in other countries (Braun, 1998), resistance to this duality in the case of the RCN hardly exists. At all levels, the governance of educational research is anchored in the national principle of consensus. As noted by an interviewed policymaker: 'Everyone cannot always have their way, but we attempt to listen to all involved parties and accommodate differing points of view as much as possible' (A V). Given the generous funding of R\&D made possible by vast revenues from oil resources and facilitated by the government's commitment to higher education and R\&D growth, distributional conflicts that are common in other countries hardly seem to exist.

\section{DISCUSSION}

Beyond the complex translation processes involved, Norway reflects common global and European trends in the governance of educational research: The reliance on thematic research programmes to expand, accelerate and even (re)shape the development of educational research through the funding of specific research projects goes far beyond symbolic agenda-setting. We define this trend as the programmification of educational research: the planned creation and strategic use of state-funded, long-term and large-scale research programmes to alter the structural and cognitive status quo of a discipline or field of research. This is not unique to the Norwegian context, as similar programmes have also been identified in Germany (Framework Programme for the Promotion of Empirical Educational Research, see Zapp \& Powell, 2016), the UK (Teaching and Learning Research Programme, see Marques et al., 2017) and the EU's Framework Programme. Importantly, this programmification of research governance has led researchers to adapt their funding acquisition strategies (and their research, incrementally) to fit themes and expectations espoused by funding bodies. This phenomenon, conceptualised as 'epistemic drift' (Elzinga, 1997), is particularly evident at the nexus of research and evidence-based policymaking in an expanded system experiencing 'academic drift' (Kaiserfeld, 2013).

The remarkable rising interest in educational research has translated into an armory of powerful ideas about education and the 'knowledge society', driven by technological change. Lasting normative pressures include those to improve quality, standards, impact and evaluation, respond to internationalisation and academic drift, publish in English and enhance professionalisation. Pervasive policy instruments have been established, most prominently funding programmes that provide educational research with monetary blessings never experienced before. Yet these investments also entail risks. Indeed, a government-appointed expert group in 2017 called for a reduction of such programmes in favour of more open programmes that provide researchers with greater autonomy to choose their topics of research (Myklebust, 2017). With the movement towards the 'knowledge society' and the quest for 'evidence' comes much 
expansion, mainly of certain kinds of educational research perceived as 'relevant', and regional and global competition. Such novel labels of legitimacy, although not necessarily edging out fundamental scientific priorities and paradigms, have reshaped the traditional science-society contract in Norwegian educational research.

\section{ACKNOWLEDGMENTS}

This research was funded by the University of Luxembourg's tandem programme for interdisciplinary research (Project: The New Governance of Educational Research, EDRESGOV). We thank Gert Biesta, Marcelo Marques, Jennifer Dusdal and Simen Kristiansen in Luxembourg, our interviewees in Norway, participants in EERA-ECER sessions in Dublin and Copenhagen and the anonymous reviewers for their insights and helpful comments on this research.

\section{ENDNOTE}

${ }^{1}$ The interviews were conducted within the larger European comparative research project EDRESGOV. All translations from the original Norwegian sources were completed by Jo B. Helgetun.

\section{REFERENCES}

Aagaard, K., Bloch, C. W., \& Schneider, J. W. (2015). Impacts of performance-based research funding systems: The case of the Norwegian publication indicator. Research Evaluation, 24(2), 106-117. https://doi.org/10.1093/reseval/rvv003

Besley, T. (2009). Assessing the quality of educational research in higher education. Rotterdam, the Netherlands: Sense.

Biesta, G. (2007). Why 'what works' won't work: Evidence-based practice and the democratic deficit. Educational Theory, 57(1), 1-22. https://doi.org/10.1111/j.1741-5446.2006.00241.x

Bleiklie, I. (1998). Justifying the evaluative state: New public management ideals in higher education. European Journal of Education, 33, 299-316.

Bleiklie, I. (2009). Norway: From tortoise to eager beaver? In C. Paradeise, E. Reale, I. Bleiklie, \& E. Ferlie (Eds.), University governance (pp. 127-152). Heidelberg, Germany: Springer.

Bleiklie, I., \& Michelsen, S. (2013). Comparing higher education policies in Europe. Higher Education, 65(1), 113-133. https://doi.org/10.1007/s10734-012-9584-6

Bogner, A., Littig, B., \& Menz, W. (2009). Interviewing experts. Basingstoke: Palgrave Macmillan.

Braun, D. (1998). The role of funding agencies in the cognitive development of science. Research Policy, 27(8), 807-821. https://doi.org/10.1016/s0048-7333(98)00092-4

Campbell Collaboration. (2016). Invited by Norway's ministry of education. Retrieved from https://www.campbellcollaboration.org/news-archive/news/invited-by-norway-s-ministry-of-education

Campbell, J. L. (2004). Institutional change and globalization. Princeton, NJ: Princeton University Press.

CEMO. (2016). About UiO centre for educational measurement. Retrieved from https://www.uv.uio.no/cemo/english/about

Chabbott, C. (2003). Constructing education for development: International organizations and education for all. New York: RoutledgeFalmer.

Chou, M.-H., \& Gornitzka, Å. (Eds.). (2014). Building the knowledge economy in Europe. Cheltenham: Edward Elgar.

Cowen, R. (2009). The transfer, translation and transformation of educational processes. Comparative Education, 45(3), 315-327. https://doi.org/10.1080/03050060903184916

Cruz-Castro, L., \& Sanz-Menéndez, L. (2007). New legitimation models and the transformation of the public research organizational field. International Studies of Management and Organization, 37(1), 27-52. https://doi.org/10.2753/ imo0020-8825370102

Czarniawska, B., \& Joerges, B. (1996). Travels of ideas. In B. Czarniawska \& G. Sevón (Eds.), Translating organizational change (pp. 13-48). Berlin, Germany: de Gruyter.

Dale, E. L. (1999). De strategiske pedagoger. Pedagogikkens vitenskapshistorie i Norge. Oslo, Norway: Ad Notam Gyldendal.

Department of Education and Research. (2005). Commitment to Research. Report no. 20 to the Storting 2004/05. Oslo, Norway. Retrieved from https://www.regjeringen.no/no/dokumenter/stmeld-nr-20-2004-2005-/id406791/

DiMaggio, P. J., \& Powell, W. W. (1983). The iron cage revisited: Institutional isomorphism and collective rationality in organizational fields. American Sociological Review, 48(2), 147-160. Retrieved from http://www.jstor.org/stable/ 2095101 
Drori, G. S., Meyer, J. W., Ramirez, F. O., \& Schofer, E. (2003). Science in the modern world polity. Stanford, CA: Stanford University Press.

Elstad, E., \& Sivesind, K. (Eds.). (2010). PISA: Sannheten om skolen? Oslo, Norway: Universitetsforlaget.

Elzinga, A. (1997). The science-society contract in historical transformation: With special reference to 'epistemic drift. Social Science Information, 36(3), 411-445. https://doi.org/10.1177/053901897036003002

Finnemore, M. (1993). International organizations as teachers of norms: The United Nations Educational, Scientific, and Cultural Organization and science policy. International Organization, 47(4), 565-597.

FINNUT. (2014). Work programme. Retrieved from http://www.forskningsradet.no

Foss Lindblad, R., Lindblad, S., \& Popkewitz, T. S. (2009). Narratives on educational research evaluations in Sweden. In T. Besley (Ed.), Assessing the quality of educational research in higher education (pp. 279-292). Rotterdam, the Netherlands: Sense.

Gläser, J., Aljets, E., Gorga, A., Hedmo, T., Håkansson, E., \& Laudel, G. (2014). Path dependence and policy steering in the social sciences: The varied impact of international large-scale student assessment on the educational sciences in four European countries. Research in the Sociology of Organizations, 42, 267-295. https://doi.org/10.1108/S0733-558X_ 2014_0000042009

Green, A. (2006). Models of lifelong learning and the "knowledge society. Compare, 36(3), 307-327. https://doi.org/ 10.1080/03057920600872449

Greenwood, R., Suddaby, R., \& Hinings, C. R. (2002). Theorizing change: The role of professional associations in the transformation of institutionalized fields. The Academy of Management Journal, 45(1), 58-80. https://doi.org/10.2307/ 3069285

Gudmundsdottir, S. (1994). Forskning på utdanning og læring. In J. Lauglo (Ed.), Norsk forskning om utdanning perspektiver og veivalg (pp. 44-79). Oslo, Norway: Ad notam Gyldendal.

Gundem, B. B. (1993). Rise, development and changing conceptions of curriculum administration and curriculum guidelines in Norway: The national-local dilemma. Journal of Curriculum Studies, 25, 251-266.

Gunnes, H. (2009). Ressursinnsatsen innenfor utdanningsforskning 2007. Oslo, Norway: NIFU.

Gunnes, H., \& Rørstad, K. (2015). Utdanningsforskning i Norge 2013: Ressurser og resultater. Oslo, Norway: NIFU.

Halvorsen, T. (1994). Forskning om yrkesutdanning og arbeidsliv-hvor går vi nå? In J. Lauglo (Ed.), Norsk forskning om utdanning. Perspektiver og veivalg (pp. 96-126). Oslo, Norway: Ad notam Gyldendal.

Helsvig, K. (2002). Pedagogikkens grenser. Kampen om pedagogikkfaget ved Universitetet i Oslo 1930-1980 (PhD dissertation). University of Oslo, Oslo, Norway.

Hwang, H. (2006). Planning development: Globalization and the shifting locus of planning. In G. S. Drori, J. W. Meyer, \& H. Hwang (Eds.), Globalization and organization (pp. 69-90). Oxford: Oxford University Press.

Jepperson, R. L. (1991). Institutions, institutional effects, and institutionalism. In W. W. Powell \& P. J. DiMaggio (Eds.), The new institutionalism in organizational analysis (pp. 143-163). Chicago, IL: University of Chicago Press.

Kaiserfeld, T. (2013). Why new hybrid organizations are formed: Historical perspectives on epistemic and academic drift. Minerva, 51(2), 171-194. https://doi.org/10.1007/s11024-013-9226-x

Karlsson, S. (2017). Evaluation as a travelling idea: Assessing the consequences of research assessment exercises. Research Evaluation, 26(2), 55-65. https://doi.org/10.1093/reseval/rvx001

Karseth, B., \& Sivesind, K. (2010). Conceptualising curriculum knowledge within and beyond the national context. European Journal of Education, 45, 103-120. https://doi.org/10.1111/j.1465-3435.2009.01418

KCE. (2016). About the knowledge centre. Retrieved from http://www.forskningsradet.no/prognett-kunnskapssenter/ About_the_Knowledge_Centre/1254009289413?lang=en

Larsen, I. M. (2000). University research policy in Norway: Walking the tightrope between internal and external interests. European Journal of Education, 35(4), 385-402.

Lauglo, J. (Ed.). (1994). Norsk forskning om utdanning. Perspektiver og veivalg. Oslo, Norway: Ad notam Gyldendal.

Lepori, B., van den Besselaar, P., Dinges, M., van der Meulen, B., Potì, B., Reale, E., ... Theves, J. (2007). Indicators for comparative analysis of public project funding. Research Evaluation, 16, 243-255.

Mahoney, J., \& Thelen, K. (Eds.). (2010). Explaining institutional change: Ambiguity, agency, and power. Cambridge: Cambridge University Press.

Maroy, C. (2009). Convergences and hybridization of educational policies around 'post-bureaucratic' models of regulation. Compare, 39(1), 71-84. https://doi.org/10.1080/03057920801903472

Marques, M., Powell, J. J. W., Zapp, M., \& Biesta, G. (2017). How does research evaluation impact educational research? Exploring intended and unintended consequences of research assessment in the United Kingdom, 1986-2014. European Educational Research Journal, 16(6), 820-842. https://doi.org/10.1177/1474904117730159 
Maylor, H., Brady, T., Cooke-Davies, T., \& Hodgson, D. (2006). From projectification to programmification. International Journal of Project Management, 24, 663-674.

MER. (2016). About the Ministry of Education and Research. Retrieved from http://www.regjeringen.no/en/dep/kd/id586/

Meyer, H.-D., \& Benavot, A. (Eds.). (2013). PISA, power and policy: The emergence of global educational governance. Oxford: Symposium Books.

Meyer, J. W., Boli, J., Thomas, G. M., \& Ramirez, F. O. (1997). World society and the nation state. American Journal of Sociology, 103(1), 144-181. https://doi.org/10.1086/231174

Meyer, J. W., \& Frank, D. J. (2007). University expansion and the knowledge society. Theory and Society, 36(4), $287-311$. http://doi.org/10.1007/s11186-007-9035-z

Myklebust, J. P. (2017, February 9). Norway: Expert group recommends overhaul of research funding. University World News. Retrieved from www.universityworldnews.com/article.php?story=20170209110657833

NC. (2016). Nordic Council of Ministers' research department Nordforsk. Retrieved from https://www.nordforsk.org/en/ programmes-and-projects/programmes/education-for-tomorrow-1

NOKUT. (2016). Centres for excellence in higher education. Retrieved from http://www.nokut.no/en/Centres-forExcellence-in-Higher-Education/

Nutley, S., Morton, S., Jung, T., \& Boaz, A. (2010). Evidence and policy in six European countries. Evidence and Policy, 6, $131-144$.

Powell, J. J. W., Baker, D. P., \& Fernandez, F. (Eds.). (2017). The century of science: The global triumph of the research university. Bingley: Emerald Publishing.

Powell, J. J. W., Bernhard, N., \& Graf, L. (2012). The emergent European model in skill formation. Sociology of Education, 85(3), 240-258. https://doi.org/10.1177/0038040711427313

Powell, J. J. W., Graf, L., Bernhard, N., Coutrot, L., \& Kieffer, A. (2012). The shifting relationship between vocational and higher education in France and Germany: Towards convergence?. European Journal of Education, 47(3), 405-423.

PRAKSISFOU. (2006). Work programme. Retrieved from http://www.forskningsradet.no

PRAKUT. (2011). Work programme. Retrieved from http://www.forskningsradet.no

RCN. (2004). Norsk pedagogisk forskning. En evaluering av forskningen ved utvalgte universeter og høgskoler. Oslo, Norway: Norges Forskningsråd.

RCN. (2006). En nasjonal strategi for norsk pedagogisk forskning. Oslo, Norway: Norges Forskningsråd.

Sahlin-Andersson, K. (1996). Imitating by editing success: The construction of organizational fields. In B. Czarniawska \& G. Sevón (Eds.), Translating organizational change (pp. 69-92). Berlin, Germany: de Gruyter.

Schneider, J. W., Aagaard, K., \& Bloch, C. W. (2015). What happens when national research funding is linked to differentiated publication counts?. Research Evaluation, 25(3), 244-256. https://doi.org/10.1093/reseval/rvv036

Schofer, E., \& Meyer, J. W. (2005). The worldwide expansion of higher education in the twentieth century. American Sociological Review, 70(6), 898-920. https://doi.org/10.1177/000312240507000602

Scott, W. R. (2013). Institutions and organizations. Thousand Oaks, CA: SAGE.

Sellar, S., \& Lingard, B. (2014). The OECD and the expansion of PISA: New global models of governance in education. British Educational Research Journal, 40(6), 917-936. https://doi.org/10.1002/berj.3120

Sivertsen, G. (2016). Publication-based funding: The Norwegian model. In M. Ochsner, S. E. Hug, \& H. D. Daniel (Eds.), Research assessment in the humanities (pp. 70-90). Cham: Springer Open.

Strand, T., \& Kvernbekk, T. (2009). Assessing the quality of educational research: The case of Norway. In T. Besley (Ed.), Assessing the quality of educational research in higher education (pp. 263-278). Rotterdam, the Netherlands: Sense.

Suárez, D., \& Bromley, P. (2016). Institutional theories and levels of analysis: History, diffusion, and translation. In J. Schriewer (Ed.), World culture re-contextualised (pp. 139-159). Abingdon: Routledge.

Suchman, M. C. (1995). Managing legitimacy: Strategic and institutional approaches. The Academy of Management Review, 20(3), 571-610. Retrieved from http://www.jstor.org/stable/258788

Telhaug, A. O. (1978). Pedagogikk og politikk. Oslo, Norway: Gyldendal.

Utdanning2020. (2010). Work programme. Retrieved from http://www.forskningsradet.no/

Weick, K. E. (1993). Organizational redesign as improvisation. In G. P. Huber \& W. H. Glick (Eds.), Organization change and redesign (pp. 346-379). Oxford: Oxford University Press.

Whitley, R., \& Gläser, J. (Eds.). (2007). The changing governance of the sciences: The advent of research evaluation systems. In Sociology of the Sciences Yearbook (Vol. XXVI). Dordrecht, the Netherlands: Springer.

Zapp, M., Marques, M., \& Powell, J. J. W. (2017). Two worlds of educational research? Comparing the levels, objects, disciplines, methodologies, and themes in educational research in the UK and Germany, 2005-2015. Research in Comparative and International Education, 12(4), 375-397. https://doi.org/10.1177/1745499917740658 
Zapp, M., \& Powell, J. J. W. (2016). How to construct an organizational field: Empirical educational research in Germany, 1995-2015. European Educational Research Journal, 15(5), 537-557. https://doi.org/10.1177/ 1474904116641422

Zapp, M., \& Powell, J. J. W. (2017). Moving towards Mode 2? Evidence-based Policy-Making and the Changing Conditions for Educational Research in Germany. Science and Public Policy, 44(5), 645-655. https://doi.org/10.1093/scipol/ scw091

How to cite this article: Zapp M, Helgetun JB, Powell JJW. (Re)shaping educational research through 'programmification': Institutional expansion, change, and translation in Norway. Eur J Educ. 2018;00:1-16. https://doi. org/10.1111/ejed.12267 